\title{
Pengaruh Model Pembelajaran Penemuan Terbimbing dalam Pembelajaran Jarak Jauh Terhadap Kemampuan Pemahaman Konsep Matematis Peserta Didik SMPN 99 Jakarta
}

\author{
Faoza Saaroh $^{1, a)}$, Lukman El Hakim ${ }^{2, b)}$, Vera Maya Santi ${ }^{3, c)}$ \\ ${ }^{1,2,3}$ Universitas Negeri Jakarta
}

Email: a) $\underline{\text { faozaSaaroh_1301617070@mhs.unj.ac.id }}$

\begin{abstract}
Abstrak
Penelitian ini bertujuan untuk mengetahui pengaruh model pembelajaran penemuan terbimbing dalam pembelajaran jarak jauh terhadap kemampuan pemahaman konsep matematis peserta didik. Penelitian dilaksanakan pada kelas VII SMPN 99 Jakarta dengan pokok bahasan segi empat dan segitiga di semester genap tahun ajaran 2020/2021. Metode penelitian quasi experiment digunakan pada penelitian ini, yakni dengan posttest only control group design. Teknik pengambilan sampel yang digunakan yaitu simple random sampling. Instrumen yang digunakan pada penelitian ini yaitu berupa instrumen tes yang terdiri dari 4 soal uraian. Instrumen telah melalui uji validitas dan reliabilitas sebelum diberikan kepada sampel. Hasil analisis data berdasarkan uji $t$ menunjukkan keputusan tolak $H_{0}$ bertaraf signifikansi $\alpha=5 \%$ karena $t_{\text {hitung }}=3,710 \geq t_{\text {tabel }}=1,665$. Berdasarkan hasil tersebut, dapat disimpulkan bahwa terdapat pengaruh yang signifikan dari penerapan model pembelajaran penemuan terbimbing dalam pembelajaran jarak jauh terhadap kemampuan pemahaman konsep matematis peserta didik SMPN 99 Jakarta. Adapun hasil perhitungan uji Cohen's $d$ yaitu sebesar 0,830 sehingga besar signifikansi pengaruh tergolong tinggi dengan persentasenya yaitu $79 \%$.
\end{abstract}

Kata kunci: model pembelajaran penemuan terbimbing, pembelajaran jarak jauh, kemampuan pemahaman konsep matematis, segi empat dan segitiga

\section{PENDAHULUAN}

Matematika merupakan salah satu mata pelajaran wajib yang memiliki peran penting dalam perjalanan peserta didik menuntut ilmu di dunia pendidikan. Sejalan dengan hal tersebut, keberhasilan dalam menuntaskan tujuan pembelajaran matematika sesuai dengan kurikulum yang berlaku merupakan harapan bagi pendidik maupun peserta didik. Tujuan utama dari pembelajaran matematika yaitu tercapainya suatu kemampuan kognitif peserta didik terkait pemahaman konsep matematis, penjelasan keterkaitan antar konsep dan penyajian konsep ke dalam berbagai representasi, serta aplikasi konsep atau algoritma secara fleksibel, akurat, efisien, dan tepat dalam rangka kegiatan pemecahan masalah matematis (Hendriyana, 2014 dalam Destiniar, Jumrah, \& Sari, 2019). Adapun indikator kemampuan pemahaman konsep matematis peserta didik SMP/MTs dipaparkan lebih lanjut dalam Permendikbud Nomor 58 Tahun 2014.

Indikator kemampuan pemahaman konsep matematis perlu dimiliki oleh setiap peserta didik. Hal tersebut demi tercapainya suatu kesinambungan dalam mencapai kemampuan matematis lainnya, seperti kemampuan dalam berkomunikasi, bernalar, memecahkan masalah, mengaitkan ide, dan merepresentasikan berbagai ide (NCTM, 2000). Kemampuan pemahaman konsep matematis peserta 
didik juga akan berpengaruh penting pada perkembangan kemampuan matematis yang lebih tinggi lagi (Romadon \& Mahmudi, 2019).

Kemampuan pemahaman konsep matematis merupakan kemampuan peserta didik yang ditandai dengan penguasaannya terhadap sejumlah materi pembelajaran sehingga dapat diungkapkan kembali dalam representasi lain serta dengan dikembangkannya konsep tersebut peserta didik mampu mengaplikasikan konsep dalam menyelesaikan masalah (Ananda, Makmuri, \& Hakim, 2020). Pemahaman konsep matematis peserta didik memiliki keterkaitan dengan penyelesaian masalah yang bersifat kompleks, yakni soal-soal yang tidak hanya mengutamakan kemampuan peserta didik dalam menghafal suatu konsep (Puspitasari \& Ratu, 2019). Dengan demikian, kemampuan pemahaman konsep matematis yaitu berupa kemampuan kognitif peserta didik pada pembelajaran matematika yang ditandai dengan keberhasilannya dalam menginterpretasikan gagasan mandiri terkait makna, implikasi, serta kesimpulan akhir dari suatu konsep berdasarkan pemahaman dasar yang telah dimiliki sehingga konsep dapat diaplikasikan untuk menyelesaikan permasalahan matematis.

Pencapaian kemampuan pemahaman konsep matematis peserta didik dapat dikatakan sebagai suatu hal yang urgensi. Namun faktanya, masih banyak peserta didik Indonesia yang mengalami kesulitan dalam mencapai indikator tersebut. Peserta didik Indonesia mendapatkan peringkat 10 besar terbawah di antara 79 negara yang berpartisipasi dalam tes PISA pada tahun 2018 (OECD, 2019). Salah satu penyebab rendahnya hasil tersebut yaitu karena ketidakmampuan peserta didik dalam merepresentasikan konsep matematis secara internal maupun eksternal sehingga peserta didik keliru ketika menyelesaikan masalah matematis (Santi, Notodiputro, \& Sartono, 2019). Persentase jumlah peserta didik Indonesia yang dapat menjawab soal UN dengan benar dari beberapa ruang lingkup matematika juga tergolong cukup rendah, yakni ruang lingkup bilangan sebesar $39,71 \%$, aljabar sebesar 51,24\%, geometri dan pengukuran sebesar $42,27 \%$, serta statistika dan peluang sebesar $55,60 \%$ (Kemendikbud, 2019). Salah satu penyebabnya yaitu karena kemampuan peserta didik dalam hal pemahaman konsep matematis yang rendah. Rendahnya kemampuan pemahaman konsep matematis peserta didik juga telah teridentifikasi berdasarkan survei pada penelitian terdahulu di SMPN 17 Pesawaran bahwa peserta didik cenderung kesulitan dalam menyelesaikan masalah non rutin yang menuntut pemahaman konsep matematis (Setiawan, Bharata, \& Caswita, 2017).

Hasil observasi terhadap peserta didik SMP Negeri 99 Jakarta selama Pembelajaran Jarak Jauh (PJJ) berlangsung menunjukkan bahwa peserta didik kesulitan dalam mencapai indikator kemampuan pemahaman konsep matematis. Hal tersebut ditunjukkan dari rendahnya hasil Penilaian Harian $(\mathrm{PH})$ peserta didik kelas VII pada materi bilangan pecahan. Persentase peserta didik pada salah satu kelas yang dipilih secara acak dalam mencapai nilai lebih dari 75 yaitu hanya sebesar $22,5 \%$ dari 40 . Mayoritas peserta didik tidak berhasil dalam mencapai indikator penyajian konsep dalam berbagai representasi dan aplikasi konsep ke dalam algoritma penyelesaian masalah. Kegagalan dalam pemahaman konsep matematis tersebut menyebabkan peserta didik kesulitan ketika memahami materi selanjutnya. Hal tersebut dijelaskan juga dalam suatu penelitian bahwa pemahaman konsep pecahan akan berkaitan dengan pemahaman aljabar karena peserta didik sejatinya akan fokus pada aspek pengetahuan matematika dasar yang telah dimiliki (Hadi \& Dedyrianto, 2020).

Penyebab terjadinya kesalahan peserta didik dalam memahami konsep matematis yaitu karena ketidaktepatan guru dalam menerapkan model pembelajaran (Novitasari, 2016). Model pembelajaran konvensional yang diterapkan oleh guru menyebabkan peserta didik hanya berperan pasif pada kegiatan pembelajaran (Nurussilmah, Santi, \& Aziz, 2020). Ketidaktepatan guru dalam menerapkan model pembelajaran matematika juga dapat disebabkan oleh kondisi kegiatan pembelajaran saat ini yang berada pada masa darurat. Mengacu pada kebijakan Kemendikbud terkait sistem PJJ di masa pandemi Covid-19, kegiatan pembelajaran memang dilaksanakan secara online dengan aturan yang dimuat pada Surat Edaran Sekretaris Jenderal Kementerian Pendidikan dan Kebudayaan Nomor 15 Tahun 2020. Kebijakan tersebut berisi pedoman penyelenggaraan PJJ. Terlepas dari fakta bahwa PJJ ini merupakan tantangan bagi pendidik maupun peserta didik, dunia pendidikan seharusnya telah memiliki persiapan yang matang dalam menentukan solusi dari masalah yang dihadapi.

Hasil observasi pada SMPN 99 Jakarta menunjukkan bahwa guru kurang memiliki persiapan selama PJJ. Platform penunjang pembelajaran matematika masih dimanfaatkan berdasarkan kegiatan pembelajaran konvensional, yakni hanya dengan memberikan bahan ajar, contoh soal yang solusinya 
secara keseluruhan diberikan oleh guru, dan latihan soal sebagai penugasan bagi peserta didik. Kegiatan diskusi secara aktif antar peserta didik dalam memahami konsep matematis tidak terlaksana selama PJJ sehingga peserta didik cenderung pasif ketika belajar matematika. Peserta didik juga menjadi kurang antusias dalam mengikuti pembelajaran sehingga hasil belajar yang diperoleh tidak dapat dicapai secara maksimal. Berdasarkan hal tersebut, perlu adanya model PJJ yang sesuai dengan ketentuan pemerintah terkait kurikulum 2013 dalam rangka meningkatkan kemampuan pemahaman konsep matematis peserta didik.

Guru harus memfasilitasi model pembelajaran yang dapat meningkatkan kemampuan pemahaman konsep matematis peserta didik di masa pandemi ini. Penerapan model pembelajaran yang tepat demi tercapainya indikator kemampuan tersebut perlu memperhatikan tipe meaningful learning (Mulyono \& Hapizah, 2018). Adapun tipe meaningful learning berdasarkan kebijakan kurikulum 2013, misalnya problem-based learning, project-based learning, dan guided discovery learning. Untuk meningkatkan pemahaman konsep peserta didik maka dipilih salah satu model yang dapat memberikan kesempatan bagi peserta didik dalam menemukan dan menyimpulkan suatu konsep berdasarkan pembentukan pengetahuannya sendiri, yakni model pembelajaran penemuan terbimbing (guided discovery learning). Peran guru adalah sebagai fasilitator bagi peserta didiknya dalam menemukan pengetahuan baru yang dibimbing oleh guru. Dilibatkannya peserta didik secara langsung selama proses penemuan konsep dari pengetahuan yang telah dimiliki maka konsep baru akan melekat lebih lama (Mawaddah \& Maryanti, 2016).

Di masa pandemi, model pembelajaran penemuan terbimbing dapat diterapkan dalam menguji indikator kemampuan pemahaman konsep matematis peserta didik. Pembelajaran online yang masih diberlakukan ini menuntut konteks kemandirian dari peserta didik dalam memahami suatu konsep. Hal itu didukung oleh hasil penelitian yang menyatakan bahwa electronic learning dengan model guided discovery memiliki efektifitas yang baik dalam pembelajaran matematika, jika ditinjau dari kemandirian peserta didik ketika memahami materi (Lu'luilmaknun \& Wutsqa, 2018).

Platform yang digunakan untuk penelitian PJJ terhadap kemampuan pemahaman konsep matematis juga perlu diperhatikan. Platform Google Classroom termasuk platform yang efektif digunakan untuk mengakses materi ajar, penugasan, dan kegiatan tanya jawab tak langsung di luar jam pelajaran (Huda, Firmansyah, Rinaldi, Suherman, Sugiharta, Astuti, Fatimah, \& Prasetiyo, 2019). Penelitian tersebut sejalan dengan salah satu platform yang digunakan oleh peserta didik di SMPN 99 Jakarta. Adapun platform pendukung lainnya yang biasa digunakan oleh sekolah tersebut dalam PJJ yaitu dengan WhatsApp dan Google Meet.

Berdasarkan uraian yang telah dipaparkan sebelumnya, model pembelajaran bermakna yang diaplikasikan pada penelitian ini dalam sistem pembelajaran jarak jauh, yakni model pembelajaran penemuan terbimbing atau guided discovery learning. Model pembelajaran ini memiliki prospek positif untuk dapat berpengaruh secara signifikan bagi kemampuan peserta didik SMP Negeri 99 Jakarta terkait pemahaman konsep matematis.

\section{METODE}

Metode penelitian ini menggunakan desain quasi experiment, yakni posttest only control group design. Populasi terjangkau pada penelitian ini yaitu peserta didik kelas VII SMP Negeri 99 Jakarta pada semester genap tahun ajaran 2020/2021. Teknik pengambilan sampel penelitian ini menggunakan simple random sampling. Teknik tersebut digunakan ketika melakukan pembatasan terhadap guru mata pelajaran matematika serta ketika memilih kelas eksperimen dan kelas kontrol. Pembatasan terhadap guru bertujuan untuk mengambil kelas terbanyak secara acak sehingga terpilih kelas VII-A sampai dengan kelas VII-E. Setelah dibatasi, uji asumsi klasik terhadap kelima kelas tersebut perlu diterapkan. Uji asumsi klasik terdiri dari uji normalitas, uji homogenitas, dan uji kesamaan rata-rata terhadap data PAS ganjil tahun ajaran 2020/2021. Apabila kelima kelas memenuhi uji asumsi klasik, maka dapat dipilih secara acak sepasang kelas yang akan dijadikan kelas eksperimen dan kelas kontrol. Kelas VII-A sebagai kelas kontrol diajar menggunakan model pembelajaran konvensional sedangkan kelas VII-D sebagai kelas eksperimen diajar menggunakan model pembelajaran penemuan terbimbing. 
Instrumen penelitian yang digunakan pada penelitian ini yaitu berupa instrumen tes kemampuan pemahaman konsep matematis pada materi bangun datar segi empat dan segitiga. Tes ini terdiri dari 4 soal uraian yang telah diuji validitas dan reliabilitasnya. Indikator kemampuan pemahaman konsep matematis yang digunakan terdiri 5 indikator, yakni pernyataan ulang sebuah konsep, klasifikasi objek berdasarkan konsep, pemberian contoh/bukan contoh konsep, penyajian konsep dalam berbagai representasi, dan aplikasi konsep dalam algoritma penyelesaian masalah.

Beberapa contoh soal yang digunakan dalam penelitian yaitu sebagai berikut.

TABEL 1. Soal Instrumen Tes Kemampuan Pemahaman Konsep Matematis

\begin{tabular}{|c|c|c|}
\hline $\begin{array}{l}\text { Indikator } \\
\text { Pembelajaran }\end{array}$ & $\begin{array}{l}\text { Indikator } \\
\text { Kemampuan }\end{array}$ & Soal \\
\hline $\begin{array}{l}\text { Menjelaskan sifat } \\
\text { bangun datar segi } \\
\text { empat dan segitiga }\end{array}$ & $\begin{array}{l}\text { Penyajian konsep } \\
\text { dalam berbagai } \\
\text { representasi dan } \\
\text { pernyataan ulang } \\
\text { konsep }\end{array}$ & $\begin{array}{l}\text { Gambarlah bangun datar segi empat dengan titik } \\
\text { koordinat } \mathrm{A}(2,-4), \mathrm{B}(6,-2), \mathrm{C}(10,-4), \\
\mathrm{D}(6,-12) \text { dan bangun datar segitiga EFG } \\
\text { dengan koordinat } \mathrm{E}(2,2), \mathrm{F}(6,2), \mathrm{G}(4,8) \text {. } \\
\text { Tuliskan sifat dari masing-masing bangun datar } \\
\text { yang terbentuk berdasarkan sisi, sudut, ataupun } \\
\text { diagonalnya. }\end{array}$ \\
\hline $\begin{array}{l}\text { Menemukan formulasi } \\
\text { keliling dan luas } \\
\text { berbagai bangun datar } \\
\text { segi empat dan segitiga } \\
\text { berdasarkan jenisnya }\end{array}$ & $\begin{array}{l}\text { Klasifikasi objek } \\
\text { berdasarkan konsep } \\
\text { dan penyajian } \\
\text { konsep dalam } \\
\text { berbagai } \\
\text { representasi }\end{array}$ & $\begin{array}{l}\text { Seorang ahli tata kota akan membuat dua buah } \\
\text { taman. Taman pertama berbentuk segitiga sama } \\
\text { sisi dengan panjang sisi }(x+3) m \text {. Taman kedua } \\
\text { berbentuk belah ketupat dengan panjang sisinya } \\
\text { yaitu }(x-3) m \text { serta panjang diagonalnya } \\
(x+2) m \text { dan }(x+1) m \text {. Jika keliling taman } \\
\text { pertama sama dengan keliling taman kedua, } \\
\text { maka hitunglah luas dari taman kedua. }\end{array}$ \\
\hline
\end{tabular}

Hasil uji validitas Aikens's $V$ instrumen tes dapat dilihat pada Tabel 2 berikut.

TABEL 2. Hasil Uji Validitas Instrumen Tes

\begin{tabular}{|c|c|c|l|}
\hline Soal & $\boldsymbol{V}$ & Keterangan & \multicolumn{1}{|c|}{ Kategori } \\
\hline 1 & 0,845 & & \multirow{2}{*}{0} \\
\cline { 1 - 2 } 2 & 0,817 & $0,70 \leq V<0,90$ & Tepat \\
\hline 3 & 0,766 & & \\
\hline 4 & 0,536 & $0,40 \leq V<0,70$ & Cukup Tepat \\
\hline
\end{tabular}

Hasil perhitungan uji reliabilitas dengan koefisien Alpha Cronbach pada tes kemampuan pemahaman konsep matematis yang terdiri dari 4 butir soal uraian yaitu $r_{11}=0,719$. Hasil perhitungan tersebut dapat dikategorikan ke dalam reliabilitas yang tepat/baik karena $0,70 \leq r_{11}<0,90$ sehingga instrumen tes dapat diterapkan sebagai alat ukur pada penelitian ini.

Teknik analisis data penelitian ini menggunakan uji $t$ karena kedua sampel bersifat independen dengan terlebih dahulu dilakukan uji normalitas dan uji homogenitas sesudah perlakuan. Selanjutnya dilakukan uji besar pengaruh menggunakan uji Cohen's $d$ untuk mengetahui besar signifikansi pengaruh dari penerapan model pembelajaran penemuan terbimbing dalam pembelajaran jarak jauh terhadap kemampuan pemahaman konsep matematis peserta didik SMP Negeri 99 Jakarta. 


\section{HASIL}

\section{Uji Prasyarat Analisis Data Sebelum Perlakuan}

Hasil uji normalitas sebelum perlakuan menggunakan uji Liliefors disajikan dalam Tabel 3.

TABEL 3. Hasil Uji Normalitas Sebelum Perlakuan

\begin{tabular}{|c|c|c|c|c|}
\hline Kelas & $L_{\text {hitung }}$ & $L_{\text {tabel }}$ & Keputusan & Interpretasi \\
\hline VII-A & 0,118 & \multirow{5}{*}{0,140} & \multirow{5}{*}{$\begin{array}{c}\text { Terima } H_{0} \\
\text { karena } L_{\text {hitung }} \leq L_{\text {tabel }}\end{array}$} & \multirow{5}{*}{ Normal } \\
\hline VII-B & 0,110 & & & \\
\hline VII-C & 0,074 & & & \\
\hline VII-D & 0,095 & & & \\
\hline VII-E & 0,098 & & & \\
\hline
\end{tabular}

Berdasarkan keputusan dan interpretasi pada Tabel 3, maka dapat disimpulkan bahwa data PAS peserta didik kelas VII-A s.d. VII-E berasal dari populasi yang berdistribusi normal dengan taraf signifikansi $5 \%$.

Hasil uji homogenitas sebelum perlakuan menggunakan uji Bartlett disajikan dalam Tabel 4.

TABEL 4. Hasil Uji Homogenitas Sebelum Perlakuan

\begin{tabular}{|c|c|c|c|}
\hline $\boldsymbol{x}^{\mathbf{2}}$ hitung & $\boldsymbol{x}_{\text {tabel }}^{\mathbf{2}}$ & Keputusan & Interpretasi \\
\hline \multirow{3}{*}{3,341} & 0,484 & Terima $H_{0}$ karena & Homogen \\
& dan & $0,484<\chi_{\text {hitung }}^{2}<11,143$ & \\
\hline
\end{tabular}

Keputusan yang diperoleh berdasarkan perhitungan pada Tabel 4 yaitu terima $H_{0}$ sehingga dapat disimpulkan bahwa kelas VII-A s.d. VII-E tersebut memiliki varians yang relatif homogen dengan taraf signifikansi $5 \%$.

Hasil uji kesamaan rata-rata menggunakan Anava satu jalur disajikan dalam Tabel 5.

TABEL 5. Hasil Uji Kesamaan Rata-rata

\begin{tabular}{|c|c|c|c|}
\hline $\boldsymbol{F}_{\text {hitung }}$ & $\boldsymbol{F}_{\text {tabel }}$ & Keputusan & Interpretasi \\
\hline \multirow{2}{*}{1,249} & 0,121 dan & Terima $H_{0}$ karena & Rata-rata sama \\
& 2,852 & $0,121<F_{\text {hitung }}<2,852$ & \\
\hline
\end{tabular}

Berdasarkan hasil perhitungan pada Tabel 3, dapat disimpulkan bahwa kelas VII-A s.d. VII-E memiliki rata-rata yang tidak berbeda signifikan dengan taraf signifikansi 5\% sehingga dapat dipilih sepasang kelas secara acak dari kelima kelas tersebut untuk dijadikan kelas kontrol dan kelas eksperimen.

\section{Uji Prasyarat Analisis Data Setelah Perlakuan}

Hasil uji normalitas setelah perlakuan menggunakan uji Liliefors disajikan dalam Tabel 6.

TABEL 6. Hasil Uji Normalitas Setelah Perlakuan

\begin{tabular}{|c|c|c|c|c|}
\hline Kelas & $L_{\text {hitung }}$ & $L_{\text {tabel }}$ & Keputusan & Interpretasi \\
\hline Eksperimen & 0,058 & \multirow{2}{*}{0,140} & Terima $H_{0}$ karena & \multirow{2}{*}{ Normal } \\
\hline Kontrol & 0,061 & & $L_{\text {hitung }} \leq L_{\text {tabel }}$ & \\
\hline
\end{tabular}


Berdasarkan keputusan dan interpretasi pada Tabel 6, dapat disimpulkan bahwa data nilai tes kemampuan pemahaman konsep matematis peserta didik kelas eksperimen dan kelas kontrol berasal dari populasi yang berdistribusi normal dengan taraf signifikansi $5 \%$.

Hasil uji homogenitas setelah perlakuan menggunakan uji Fisher disajikan dalam Tabel 7.

TABEL 7. Hasil Uji Homogenitas Setelah Perlakuan

\begin{tabular}{|c|c|c|c|}
\hline $\boldsymbol{F}_{\text {hitung }}$ & $\boldsymbol{F}_{\text {tabel }}$ & Keputusan & Interpretasi \\
\hline \multirow{2}{*}{1,749} & 0,529 & Terima $H_{0}$ karena & \multirow{2}{*}{ Homogen } \\
& dan & $0,529<F_{\text {hitung }}<1,891$ & \\
\hline
\end{tabular}

Berdasarkan hasil perhitungan pada Tabel 7, dapat disimpulkan bahwa data posttest kemampuan pemahaman konsep matematis peserta didik kelas eksperimen dan kelas kontrol pada penelitian ini memiliki varians yang relatif homogen dengan taraf signifikansi $5 \%$.

\section{Uji Analisis Data}

Hasil uji hipotesis penelitian menggunakan uji $t\left(\sigma_{1}^{2}=\sigma_{2}^{2}\right)$ disajikan dalam Tabel 8 .

TABEL 8. Hasil Uji Hipotesis Penelitian

\begin{tabular}{|c|c|c|}
\hline $\boldsymbol{t}_{\text {hitung }}$ & $\boldsymbol{t}_{\text {tabel }}$ & \multicolumn{1}{c|}{ Keputusan } \\
\hline 3,710 & 1,665 & $\begin{array}{l}\text { Tolak } H_{0} \text { karena } \\
t_{\text {hitung }}>t_{\text {tabel }}\end{array}$ \\
\hline
\end{tabular}

Berdasarkan Tabel 8, dapat disimpulkan dengan taraf signifikansi 5\% bahwa rata-rata kemampuan pemahaman konsep matematis peserta didik dalam pembelajaran jarak jauh yang diajar dengan model pembelajaran penemuan terbimbing lebih tinggi dibandingkan peserta didik yang diajar dengan menggunakan model pembelajaran konvensional.

\section{Uji Besar Pengaruh}

Hasil uji besar pengaruh menggunakan uji Cohen's $d$ disajikan dalam Tabel 9.

TABEL 9. Hasil Uji Besar Pengaruh

\begin{tabular}{|c|c|c|}
\hline \multicolumn{3}{|c|}{ TABEL 9. Hasil Uji Besar Pengaruh } \\
\hline $\boldsymbol{d}$ & Kategori & Persentase \\
\hline 0,830 & Besar & $79 \%$ \\
\hline
\end{tabular}

Berdasarkan hasil perhitungan pada Tabel 9, dapat disimpulkan bahwa kategori signifikansi pengaruh penerapan model pembelajaran penemuan terbimbing dalam pembelajaran jarak jauh terhadap kemampuan pemahaman konsep matematis peserta didik SMPN 99 Jakarta berada pada kategori yang besar dengan persentasenya yaitu $79 \%$.

\section{PEMBAHASAN}

Hasil pengujian hipotesis bertaraf signifikansi 5\% yang telah dijelaskan sebelumnya menyatakan bahwa pada PJJ di SMPN 99 Jakarta ini peserta didik kelas eksperimen yang diajar menggunakan model pembelajaran penemuan terbimbing memiliki rata-rata nilai posttest kemampuan pemahaman konsep matematis yang lebih tinggi dibandingkan kelas kontrol yang diajar dengan model pembelajaran konvensional. Hasil tersebut menunjukkan bahwa penerapan model pembelajaran penemuan terbimbing dalam PJJ memiliki pengaruh yang signifikan terhadap kemampuan pemahaman konsep matematis, yakni model pembelajaran tersebut dinilai lebih baik untuk diterapkan daripada 
model pembelajaran konvensional. Pengaruh signifikansi tersebut tergolong pada kategori yang besar karena hasil perhitungannya menyatakan persentase tingkat pengaruh sebesar 79\%.

Rata-rata nilai tes kemampuan pemahaman konsep matematis peserta didik kelas eksperimen pada materi segi empat dan segitiga yaitu sebesar 70,234 sedangkan pada kelas kontrol yaitu sebesar 57,031. Rata-rata nilai tes kelas eksperimen lebih tinggi daripada kelas kontrol. Data nilai tersebut menyatakan bahwa nilai terendah peserta didik kelas eksperimen yaitu 43,75 sedangkan nilai tertingginya yaitu 93,75. Nilai tertinggi kelas kontrol yaitu 90,625 sedangkan nilai terendahnya yaitu 18,75. Kebijakan nilai KKM untuk mata pelajaran matematika di SMPN 99 Jakarta yaitu sebesar 75. Pada kelas eksperimen, terdapat 17 peserta didik yang berhasil mencapai KKM pada posttest kemampuan pemahaman konsep matematis sedangkan pada kelas kontrol hanya sebanyak 9 peserta didik.

Keunggulan secara statistik terkait hasil tes kemampuan pemahaman konsep matematis yang diperoleh kelas eksperimen dan kelas kontrol telah dipaparkan sebelumnya. Keunggulan kelas eksperimen dapat diperoleh karena adanya perbedaan perlakuan model pembelajaran yang diterapkan selama PJJ pada penelitian ini. Model pembelajaran penemuan terbimbing yang telah diterapkan pada kelas eksperimen sebelum diberikannya posttest kemampuan pemahaman konsep matematis pada materi segi empat dan segitiga ini dapat mendukung alasan terhadap hasil statistik yang diperoleh tersebut.

Syntax model pembelajaran penemuan terbimbing yang diterapkan pada kelas eksperimen yaitu terdiri dari 5 tahapan. Tahapan itu terdiri dari perumusan dan identifikasi masalah, pengembangan data, pengolahan data, verifikasi, serta tahap yang terakhir yaitu implementasi dengan latihan. Kelima tahapan tersebut secara keseluruhan telah memberikan pengalaman pembelajaran kepada peserta didik terkait makna tersirat dari beberapa indikator kemampuan pemahaman konsep matematis pada penelitian ini.

Pada tahap pertama, peserta didik dihadapkan pada suatu masalah terkait materi segi empat dan segitiga yang telah dirumuskan oleh guru. Masalah tersebut selanjutnya diidentifikasi oleh peserta didik. Masalah disajikan oleh guru melalui LKPD yang dilampirkan pada platform Google Classroom. Pada tahap ini, peserta didik melakukan klasifikasi terhadap beberapa data yang telah disediakan pada LKPD berdasarkan konsep dasar yang telah dimiliki untuk dikembangkan lebih lanjut dalam perencanaan penyelesaian masalah. Kegiatan yang dilakukan oleh peserta didik ini mencerminkan indikator kemampuan pemahaman konsep matematis, yakni klasifikasi objek berdasarkan konsep.

Pada tahap kedua, peserta didik mengembangkan data yang tersedia pada LKPD. Permasalahan pada LKPD yang telah diidentifikasi bersama kelompok melalui WhatsApp Group selanjutnya dapat dikembangkan melalui alternatif solusi dengan memberikan contoh data. Contoh data tersebut diambil melalui berbagai sumber yang sesuai dengan konsep tertentu agar dapat diolah. Guru mengawasi segala hal yang didiskusikan oleh setiap kelompok agar alur berpikir peserta didik tidak menyimpang dari konsep baru yang akan diperoleh nantinya. Peserta didik dalam kelompok juga saling bertukar pendapat agar solusinya tidak keliru. Pada tahap ini, terkandung indikator pemahaman konsep matematis yaitu pemberian contoh dan bukan contoh konsep.

Pada tahap ketiga, alternatif solusi yang telah direncanakan selanjutnya diolah bersama kelompok masing-masing melalui WhatsApp Group. Seluruh peserta didik dalam kelompok melakukan pengolahan data. Hasil yang diperoleh setiap individu selanjutnya dikonfirmasi dengan kelompoknya masing-masing. Hasil tersebut disajikan oleh peserta didik baik dalam bentuk grafik, tabel, ataupun model matematika sesuai materi yang sedang dipelajari. Apabila ada perbedaan, peserta didik berdiskusi untuk menetapkan pendapat yang dinilai tepat. Beberapa kelompok juga melakukan konfirmasi kepada guru terkait hasil pengolahan data yang telah ditetapkannya tersebut. Tahap ini mengandung indikator pemahaman konsep matematis yaitu penyajian konsep dalam berbagai representasi matematis.

Pada tahap keempat, peserta didik melakukan verifikasi terhadap kesimpulan sementara yang telah disusun berdasarkan hasil pengolahan data. Kelompok yang telah berhasil menyatakan konsep sementara yang diperoleh berdasarkan gagasan mandiri selanjutnya melakukan konfirmasi terhadap guru melalui WhatsApp Group. Setelah itu, seluruh kelompok diarahkan untuk melakukan pertemuan pada Google Meet. Beberapa kelompok melakukan presentasi dan kelompok lainnya menanggapi hasil 
diskusi. Kesimpulan yang dibuat oleh masing-masing kelompok secara keseluruhan sudah sesuai dengan konsep. Guru memberikan penguatan akhir terkait konsep tersebut. Pada tahap ini, indikator pemahaman konsep matematis yang terkandung yaitu pernyataan ulang sebuah konsep.

Pada tahap terakhir, peserta didik diberikan latihan soal oleh guru melalui Google Classroom. Selain keberhasilan kelompok dalam menemukan konsep, keberhasilan peserta didik secara individu dalam menyelesaikan penugasan di setiap pertemuan juga dapat menjadi salah satu nilai kesuksesan terkait model pembelajaran yang diterapkan. Pada tahap ini, peserta didik melaksanakan kegiatan yang berkaitan dengan indikator kemampuan pemahaman konsep matematis yaitu berupa aplikasi konsep dalam algoritma penyelesaian masalah.

Model pembelajaran konvensional yang diterapkan pada kelas kontrol menunjukkan tahapan yang berbeda dengan model penemuan terbimbing. Pada model konvensional, guru mengambil peran secara keseluruhan terhadap konsep dari materi yang dipelajari setiap pertemuannya. Model pembelajaran konvensional yang diterapkan oleh sekolah pada penelitian ini terdiri dari 3 tahap dengan platform pembelajaran yang sama seperti pada kelas eksperimen.

Pada tahap pertama, guru menyampaikan materi pembelajaran secara verbal melalui file yang telah dilampirkan pada Google Classroom. Pada tahap ini, peserta didik mengamati materi dan dapat bertanya kepada guru melalui WhatsApp Group. Peserta didik secara pasif menerima konsep yang telah disusun oleh guru pada file materi tanpa adanya pemberian kontribusi dari peserta didik dalam membangun konsep. Setelah mengamati materi, peserta didik mengerjakan LKPD yang telah disediakan oleh guru pada Google Classroom. Beberapa peserta didik dapat menyelesaikan LKPD dengan baik. Selanjutnya, guru dan peserta didik melakukan pertemuan melalui Google Meet. Soal pada LKPD dibahas oleh guru dan peserta didik hanya menyimak penjelasan guru secara pasif. Tahap terakhir dari model pembelajaran konvensional yaitu penugasan. Peserta didik diberikan tugas oleh guru melalui Google Classroom. Tugas tersebut perlu diselesaikan oleh peserta didik sesuai waktu yang telah ditentukan.

Kebijakan PJJ yang ditetapkan oleh Kemendikbud dianggap sebagai komponen pendukung model pembelajaran penemuan terbimbing di masa pandemi. Hal itu berkaitan dengan kemampuan kognitif peserta didik yang dianggap penting dalam PJJ, yakni pemahaman konsep. Peran peserta didik untuk berdiskusi secara virtual juga ditetapkan dalam kebijakan tersebut. Peserta didik harus aktif dalam mengikuti PJJ dan guru harus menerapkan model pembelajaran bermakna. Dengan demikian, model pembelajaran penemuan terbimbing memang lebih didukung untuk diterapkan dalam PJJ dibandingkan dengan model pembelajaran konvensional untuk kepentingan pemahaman konsep matematis peserta didik.

Penelitian ini juga didukung oleh penelitian relevan yang menyatakan bahwa model penemuan terbimbing memberikan pengaruh positif terhadap kemampuan pemahaman konsep matematis (Agustina, Gunowibowo, \& Wijaya, 2019). Model penemuan terbimbing juga dapat dikombinasikan dalam pembelajaran online yang didukung oleh platform (Lu'luilmaknun \& Wutsqa, 2018). Penerapan model pembelajaran yang mengutamakan kegiatan diskusi kelompok secara online dalam menemukan suatu konsep juga dinilai efektif untuk meningkatkan kemampuan pemahaman konsep matematis (Prawestri, Sudiarta, \& Astawa, 2020). Hal tersebut mendukung alasan bahwa model pembelajaran penemuan terbimbing dapat dijadikan alternatif dalam PJJ.

\section{PENUTUP}

\section{Kesimpulan}

Kesimpulan berdasarkan rumusan masalah, hasil analisis data, dan pembahasan yang telah dipaparkan sebelumnya menunjukkan bahwa terdapat pengaruh yang signifikan dari penerapan model pembelajaran penemuan terbimbing dalam pembelajaran jarak jauh terhadap kemampuan pemahaman konsep matematis peserta didik SMP Negeri 99 Jakarta. Peserta didik yang diajar dengan model pembelajaran penemuan terbimbing memperoleh rata-rata hasil tes kemampuan pemahaman konsep maematis yang lebih tinggi dibandingkan dengan peserta didik yang diajar dengan model pembelajaran konvensional. Hal tersebut berdasarkan hasil uji hipotesis penelitian menggunakan uji $t$, yakni pada 
penelitian ini dengan varians data yang relatif homogen menunjukkan keputusan tolak $H_{0}$ karena $t_{\text {hitung }}=3,710 \geq t_{\text {tabel }}=1,665$ bertaraf signifikansi $\alpha=5 \%$. Adapun hasil uji besar pengaruh menggunakan uji Cohen's $d$ menunjukkan bahwa besar signifikansi pengaruhnya yaitu tergolong tinggi dengan presentase $79 \%$.

Rekomendasi topik penelitian ini untuk penelitian selanjutnya yaitu terkait aplikasi model pembelajaran penemuan terbimbing dengan materi ajar, jenjang kelas, alokasi waktu, platform pembelajaran, serta sekolah yang berbeda. Komposisi indikator pemahaman konsep matematis dan syntax model pembelajaran juga dapat dikembangkan dengan aspek yang berbeda sesuai kebutuhan pada penelitian selanjutnya.

\section{REFERENSI}

Agustina, M., Gunowibowo, P., \& Wijaya, A. P. (2019). Pengaruh model penemuan terbimbing terhadap pemahaman konsep matematis. Jurnal Pendidikan Matematika Unila, 7(2), 194-208. http://repository.lppm.unila.ac.id/15379/

Ananda, M. I., Makmuri, \& Hakim, L. El. (2020). Upaya Meningkatkan Kemampuan Pemahaman Konsep Matematika Siswa dengan Model Pembelajaran Jigsaw Berbantuan Geogebra di Kelas XI IPS 1 SMA Diponegoro 1 Jakarta. Jurnal Riset Pembelajaran Matematika Sekolah, 4(1), 20 29. https://doi.org/10.21009/jrpms.041.04

Destiniar, Jumroh, \& Sari, D. M. (2019). Kemampuan pemahaman konsep matematis ditinjau dari self efficacy siswa dan model pembelajaran think pair share (TPS) di SMP Negeri 20 Palembang. Jurnal Penelitian Dan Pembelajaran Matematika, 12(1), 115-128. https://doi.org/10.30870/jppm.v12i1.4859

Hadi, A. La, \& Dedyrianto. (2020). Analisis data miskonsepsi siswa sekolah menengah pertama dalam menyelesaikan operasi aritmatika dasar. Al-Ta'dib: Jurnal Kajian Ilmu Kependidikan, 13(1), 18 33. https://doi.org/http://dx.doi.org/10.31332/atdbwv13i1.1733

Huda, S., Firmansyah, M., Rinaldi, A., Suherman, S., Sugiharta, I., Astuti, D. W., Fatimah, O., \& Prasetiyo, A. E. (2019). Understanding of mathematical concepts in the linear equation with two variables: impact of e-learning and blended learning using google classroom. Al-Jabar : Jurnal Pendidikan Matematika, 10(2), 261-270. https://doi.org/10.24042/ajpm.v10i2.5303

[Kemendikbud] Kementerian Pendidikan dan Kebudayaan. (2019). Laporan hasil ujian nasional. https://hasilun.puspendik.kemdikbud.go.id

Lu'luilmaknun, U., \& Wutsqa, D. U. (2018). Efektivitas media e-learning dengan metode guided discovery ditinjau dari kemandirian belajar matematika siswa. AKSIOMA: Jurnal Program Studi Pendidikan Matematika, 7(3), https://doi.org/http://dx.doi.org/10.24127/ajpm.v7i3.1572

413-424.

Mawaddah, S., \& Maryanti, R. (2016). Kemampuan pemahaman konsep matematis siswa SMP dalam pembelajaran menggunakan model penemuan terbimbing (discovery learning). EDU-MAT: Jurnal Pendidikan Matematika, 4(1), 76-85. https://doi.org/10.20527/edumat.v4i1.2292

Mulyono, B., \& Hapizah, H. (2018). Pemahaman konsep dalam pembelajaran matematika. $\begin{array}{llll}\text { KALAMATIKA Jurnal Pendidikan Matematika, 3(2), 103-122. } & \text {. }\end{array}$ https://doi.org/10.22236/kalamatika.vol3no2.2018pp103-122

[NCTM] National Council of Teachers of Mathematics. (2000). Principles and standards for school mathematics. Key Curriculum Press. https://b-ok.cc/book/896941/6cba3d

Novitasari, D. (2016). Pengaruh penggunaan multimedia interaktif terhadap kemampuan pemahaman 
konsep matematis siswa. FIBONACCI: Jurnal Pendidikan Matematika Dan Matematika, 2(2), 8-18. https://doi.org/10.24853/fbc.2.2.8-18

Nurussilmah, R., Santi, V. M., \& Aziz, T. A. (2020). Pengaruh pembelajaran SAVI (Somatic, Auditory, Visual, Intellectual) terhadap kemampuan pemecahan masalah ditinjau dari tingkat kemampuan awal matematika siswa SMK. Jurnal Riset Pembelajaran Matematika Sekolah, 4(2), 26-34. https://doi.org/10.21009/jrpms.042.04

[OECD] Organisation for Economic Cooperation and Development. (2019). PISA 2018 results (volume I): what students know and can do: Vol. I. OECD Publishing. https://doi.org/10.1787/5f07c754en

Prawestri, P. Y., Sudiarta, I. G. P., \& Astawa, I. W. P. (2020). The effect of online discussion in blended learning on students' mathematical concept comprehension and attitude. Journal of Physics: Conference Series, 1503(1), 1-8. https://doi.org/10.1088/1742-6596/1503/1/012017

Puspitasari, \& Ratu, N. (2019). Deskripsi pemahaman konsep siswa dalam menyelesaikan soal PISA pada konten space and shape. Mosharafa: Jurnal Pendidikan Matematika, 8(1), 155-166. https://doi.org/https://doi.org/10.31980/mosharafa.v8i1.431

Romadon, S., \& Mahmudi, A. (2019). Penerapan pendekatan penemuan terbimbing untuk meningkatkan kemampuan pemahaman konsep matematis siswa. AKSIOMA: Jurnal Program Studi Pendidikan Matematika, 8(1), 58-64. https://doi.org/10.24127/ajpm.v8i1.1684

Santi, V. M., Notodiputro, K. A., \& Sartono, B. (2019). Variable selection methods applied to the mathematics scores of Indonesian students based on convex penalized likelihood. Journal of Physics: Conference Series, 1402(7), 0-6. https://doi.org/10.1088/1742-6596/1402/7/077096

Setiawan, W., Bharata, H., \& Caswita. (2017). Pengaruh discovery learning terhadap pemahaman konsep matematis siswa. Jurnal Pendidikan Matematika Unila, 5(9), 1027-1039. 